\title{
Share repurchase: Does it increase the informativeness of market prices?
}

Hubert de La Bruslerie ${ }^{1}$

Professor of Finance, University Paris-Dauphine, DRM Finance UMR 7088, Place du Mal de Lattre 75116, Paris (France)

Abstract:

Share repurchases are transactions which are supposed to cause a market reaction through a signaling approach. However looking only at cumulated abnormal returns (CARs) is insufficient and the results are sometimes contradictory. We introduce the concept of informativeness to assess if repurchases improve the private information content of stock prices. Our empirical test comprises American and European buybacks in the period 1990-2011. We use the synchronicity measure introduced by Roll (1988) to follow the change in informativeness before and after the announcement of a transaction. The determinants of informativeness and CARs are also investigated. Our results are negative: Informativeness does not systematically improve, but may sometimes if a change of dividend policy jointly occurs.

Keywords: Share repurchase, buybacks, market efficiency, informativeness JEL: G14, G30, G35

\section{$\underline{18 / 04 / 2013}$}

\footnotetext{
${ }^{1}$ Tel : +(33) 144054327 ; E-mail: hlb@dauphine.fr.
} 


\section{Share repurchase: Does it increase the informativeness of market prices?}

\section{Introduction}

Share repurchase is a way to cash out investors which has become used increasingly in the US and recently in Europe. Following a signaling approach, we question if the signal issued by managers is useful. Does buyback effectively disseminate private information in the market?

The traditional way to tackle this problem is to look at abnormal returns. Repurchases are discretionary decisions and the market's immediate reaction is used to check if this signal effectively modifies the stock price. This traditional approach compares a signal, which is supposed to be positive, with expected positive abnormal returns. We do not follow this approach; instead, we prefer to use the idea of the informativeness of the market price. This refers to the private information content of the stock price after the transaction, not on its announcement date. Following Roll's (1988) intuition, a lower level of synchronicity between the stock price and the market return after a given event will indicate that the specific risk expands and incorporates new specific information.

We show that the informativeness of stock prices is not systematically modified by a share repurchase decision. The changes are not univocal. Sometimes informativeness improves and benefits outside investors. Sometimes it decreases. The signaling theory gives only a partial explanation of this situation and focusses only on the market reaction on or around the event date, whereas informativeness is a tool that goes further and beyond. Share repurchase is a signal of value but it is also a signal developed in a global communication policy, i.e., in a situation where the asymmetry of information is the rule between the firm and outside investors. The conclusion is that share repurchase in some situations may improve the informativeness of the stock price to investors but these situations are not frequent. Except when linked with dividend policy signals, share repurchases are signals which do not increase informativeness of the stock price. Occasionally, but not systematically, they signal undervaluation of the stock price relative to its past record and may result in negative market reaction because of poor prospects in the future. 
The rest of the paper is divided into four parts. Section 2 reviews the relevant literature. Section 3 presents the informativeness concept and the hypotheses. Section 4 contains the variables and descriptive statistics. Section 5 is devoted to the empirical tests. A conclusion follows in Section 6.

\section{Literature}

Although firms may repurchase their shares for many different motives (Dittmar, 2000), buybacks have often been analyzed following the payout policy perspective. Grullon and Michaely (2002) analyzed share repurchases in the USA. They support the substitution hypothesis in that firms repurchase their share with funds that would otherwise have been used to pay dividends. The reason for the development of share repurchase is the favorable tax treatment of capital gains compared to revenues.

However, although taxation may explain the structural or long term policy behind share repurchase as it is a structural motive, it does not explain change in payout devices or the timing of repurchase. Information asymmetry explains discretionary timing as the payout decision is a signal issued to the shareholders. Compared to dividends, share repurchase is seen as a less informative and clear signal (John and Williams, 1985; Bernheim, 1991). Allen, Bernardo and Welch (2000) consider that the dividend is a better tool to signal the firm's quality. If confirmed, it means that dividends and repurchases are not interchangeable signals. Moreover the market reaction to a dividend reduction is not negatively significant if the firm experienced share repurchase, meaning that investors do consider payout payments globally whatever their form.

Eberhart and Siddique (2005) consider a sample of 7079 US buybacks between 1981 and 1995. They show that buybacks are a first step in a financing decision because they are followed by an issue of shares. The net cash-flow to the firm is null; i.e. capital decreases are globally balanced by future capital increases. They do not confirm the signaling hypothesis as the future operating performance does not increase following a buyback.

Another reason for the positive reaction of price is that buybacks may develop liquidity of the stock in the market because the positive signal will attract new investors. This argument has been challenged, particularly by Ginglinger and Hamon (2007) who 
consider that share repurchase may have negative consequences for market liquidity. Using a sample of French share repurchases they show that the bid-ask spreads reduce.

Grullon and Michaely (2004) analyze the consequences of a repurchase program for the future performance of a firm. They find that there is no rational and positive signal in that the operating performance does not increase compared with peer firms. They contradict the hypothesis of signaling better prospects. However, the repurchasing firms experience a decline in their systematic risk and consequently in their cost of capital. This explains why a positive reaction occurs in the stock market price at the time of the announcement. The free cash flow hypothesis is also supported by their result because the repurchase signals an overinvestment situation. The reduction in investment perspective will cause their systematic risk to decrease when returning their investment to shareholders. To support the free cash flow hypothesis, overinvestment is identified as a reduction in capex after the repurchase or a decline in cash and securities holdings. The crucial hypothesis of Grullon and Michaely's setting is that repurchase occurs at a very specific moment in the firm's development. The profitability of its investment opportunities declines. At that time they claim that the systematic risk declines and as a result their cost of capital is also expected to decline (Berk et al., 1999). It can be argued that a squeeze of the opportunity set of the firm in terms of its existing assets does not imply that options for growth or future products are more risky per se. Overinvestment does not depend only on a possibly reduced reinvestment rate but also on the internally generated cash flow.

A reduction in the systematic risk is effectively identified by Grullon and Michaely during the three year period following the repurchase. The positive reaction of the market to this negative event (i.e. a decline in investment opportunities) is explained by the reaction of investors who are aware of the decline in systematic risk and in the cost of capital. Their sample includes regulated and utility firms (34\% of the total).

In the signaling approach, we can expect two different consequences of repurchase according to where the information asymmetry is. They are not mutually exclusive. The common analysis of buyback as a signal is that it should be positive because the firm is demonstrating concern about the efficient use of its equity capital (Jensen, 1986). It avoids dissipating its free cash flow; this signals that future profit per share should increase. Managers have private information; they buy undervalued shares to signal 
good future prospects which are not valued in the current price (Vermaelen, 1984). On the other hand, managers may also want to signal an abnormally depreciated stock price and support the shareholders' return. If the latter is true, buyback will follow a (relative) decrease in the market price. The difference between these two hypotheses is tiny. The first is directed more toward the future and the latter looks at the past (Benartzi et al., 1997). However in the first case, buyback will be random and follow the timing and willingness of opportunistic insiders. In the second case, buyback will develop when there has been a fall in the stock price.

The timing/agency hypothesis implies that the price of the share repurchase will be lower than the price in the subsequent days, meaning that the managers want to signal that the share has been undervalued relative to its prospects. This hypothesis predicts that future earnings (and other measures of profitability) should improve after repurchase announcements (Grullon and Michaely, 2004, p.652). This is questioned both by Eberhard and Siddique (2005) and Ginglinger and Hamon (2007). The price support hypothesis means that the repurchase price is lower than the market price of previous days, so the impulse is to support the price. Ginglinger and Hamon (2007) propose evidence consistent with the price support hypothesis.

\section{Informativeness and hypotheses}

\subsection{Informativeness}

Signaling theory has been tested viewing only market reaction identified through CARs. However, if the idea is that the buyback transaction sends a positive signal about the future of the firm, considering only the market reaction is not sufficient. It may effectively correct past undervaluation and from that perspective CARs are well adapted measures. However, when considering future prospects, signaling involves incorporating specific and new information that was not known before. In that sense, the signal expands the set of specific idiosyncratic information and consequently the firm's systematic risk. Thus, the CAR may be an insufficient measure. This is why, for instance, Grullon and Michaely (2004) look at the long-term operational performance of the firm. There is another theoretical reason which may explain why the CAR is not totally relevant: Rational investors consider the payout globally as the sum of the cash- 
flows they receive and/or pay. They know that an issue of equity may balance or even offset the repurchase flow, so the signal is weakened and may become insignificant. We can have situations of non-significant CARs although the firm issues a significant signal through share repurchase.

We need another measure of the signaling content of share repurchase to complement the immediate market reaction which can be mixed or moderated, and we introduce the broader idea of informativeness. The signal covers private information useful to the market participants. If it is not useful, it is not pure noise. This information is specifically oriented to the firm's prospects and not linked to the global market return. The quantity of private information spread into the stock price is measured by a decrease in synchronicity of the stock price versus the market moves because the specific risk of the stock has increased. If the information is useless or the signal is poor, the specific risk will stay the same, as will synchronicity. Many studies have used the measure of nonsynchronicity to assess the consequences of a given event or situation: IFRS introduction (Beuselink et al., 2010; Loureiro and Taboada, 2012), corporate cash holdings (Frésard, 2012), investment decision (Chen and Goldstein, 2007), international market comparison (Jin and Myers, 2006).

Non-synchronicity as a measure of specific private information delivered to the market is calculated using the R2 variable. This measure was first introduced by Roll (1988). As explained by Durnev, Morck and Yeung (2004), in the absence of firm-specific information, a firm's stock return varies only because of exogenous shocks in industry and market returns. In contrast, the presence of firm-specific information magnifies the stock price, rendering the returns less correlated with market and industry returns. Hence, stock price informativeness increases when the return on a stock becomes less correlated with market and industry returns. A substantial amount of evidence supports the informational content captured by this measure and particularly the amount of private information about firms.

The R2 values are calculated using weekly price moves. We consider 32-week windows before and after the announcement. Weekly observations are better suited than daily observations because sometimes daily moves are not available. As a result, missing dates are often replaced in databases by doubling the previous quote, generating 
artificial zero moves in the regressions; therefore, in line with Durnev, Morck and Yeung (2004), we chose weekly observations.

The following models are estimated:

$$
\begin{aligned}
& R_{i, t}=a_{i}+b_{i} R_{m, t}+\varepsilon_{i, t} \\
& R_{s, t}=a_{s}+b_{s} R_{m, t}+\varepsilon_{s, t} \\
& R_{i, t}=a_{m, s}+b_{m, s} R_{m, t}+c_{m, s} \varepsilon_{s, t}+\varepsilon_{s, t}
\end{aligned}
$$

Subscript $t$ belongs either to the "before" or the "after" windows.

The first equation (1) is the simple market model. It is used as a benchmark to assess the importance of the industry effect. We regress the industry index on the market index in (2). This regression takes into account the known fact that industry indexes are rather strongly correlated with market indexes. From this we get residuals $\varepsilon_{s, t}$ which are used in our R2 model. This is a means of having uncorrelated explicative variables. The test of the significance of the industry indexes is suited preferably to using this two-step model. Of course, the $\mathrm{R} 2$ of a regression using the two indexes $R_{m}$ and $R_{s}$ directly as explicative variables is the same in the end.

The indexes used are the Stoxx600 index for European firms and the Stoxx North America 600. The Stoxx 600 Europe index covers 18 European countries (including the UK) and is euro based. The Stoxx 600 North America index covers US and Canadian firms and is US dollar based. Both have industry sub-indexes. We used 19 industry or sector categories.

To compute the synchronicity measure, we follow Morck et al. (2000) and define stock return synchronicity as:

$$
S=\log (R 2 /(1-R 2))
$$

where R2 is the coefficient of determination obtained from estimating the model (3). We recall that synchronicity is the inverse of informativeness. The log transformation changes the R2 variable, bound by zero and one, into a continuous variable with a more normal distribution. This is commonly referred to in the literature (Durnev, Morck and Yeung, 2004). 
By construction, the higher values of this variable reflect higher stock return synchronicity and lower firm-specific informativeness of stock prices. We expect the R2 and $S$ to decrease between "before" and "after" because of the delivery of some private information due to the completion of the acquisition process.

Durnev et al. (2003) and Piotroski and Roulstone (2004) compute the stock return synchronicity for the calendar year. This approach is not relevant here because a possible breakdown is not linked to the calendar year but to the random announcement of a transaction. A neutral period around the announcement date is acknowledged. This period is $[-7,+7]$ calendar days around the announcement date. We decide to neutralize seven days before because the project of repurchase may diffuse to privileged investors or to analysts. Thus, the stock price may move due to insiders. It has been suggested that the premium in acquisition transactions should be computed two to four weeks before the transaction date (Martynova and Renneboog, 2009). A time period of seven days after the announcement date is necessary for the transaction to be assessed by investors. The date $t$ is the announcement. The consequences of effective repurchase may be enduring. Durnev et al. (2003) and Piotroski and Roulstone (2004) used larger yearly windows to calculate the R2 values. We consider windows of 32 weeks before and 32 weeks after the neutral period. Therefore, the two calculation periods are [-33, 1] weeks before and $[1,33]$ weeks after the announcement.

\subsection{Synchronicity estimation}

Share repurchases are taken from the Thomson Financial database for the period from 1990 to 2011. Transactions are filtered to meet the following criteria:

- only completed deals;

- a minimum value of USD 50 million;

- publicly listed firms;

- incorporated either in Europe or in North-America; ${ }^{2}$

- no government agencies, banks or financial intermediaries;

- only repurchase and self-tender;

\footnotetext{
${ }^{2}$ The countries are restricted to Belgium, France, Germany, Italy, the Netherlands, Spain, the United Kingdom, the USA, and Canada.
} 
- only repayment by cash (or cash dividend).

The basic sample comprises 1006 firms. These restricted criteria were chosen to enable examination of significant transactions. Small operations will not put the firm in a situation where disclosing information is important. Looking at developed countries means that public acquisitions should conform to a regulated process either in the EU or in the USA. This regulation implies the delivery of some information to the target shareholders. As we are measuring the specific private information in the firm's market using the stock price, we need this market to be regulated and to be subject to homogenous regulations.

We calculate the synchronicity between the stock return and the market indices. The synchronicity is given by the R2 of the regression. In order to compare the $S$ estimates, we use two similar windows of 32 observations before and after the announcement. The average $\mathrm{R} 2$ resulting from the sample is 0.28 before and 0.30 after. $^{3}$ It therefore increases with time. However it should be considered in line with the global overall increase in the sectorial R2s with their market index. The R2s of sector indexes when regressed on the market index increase from an average value of 0.61 before to an average of 0.64 after the event. This means that the increase in individual R2s can be explained by an increase in synchronicity of the sectorial R2 entered in regression (3). So we correct the individual R2 variations by the sectorial R2 variations. The corrected R2s show a similar synchronicity. ${ }^{4}$ We compute synchronicity as continuous variables $S$ $=\log (R 2 /(1-R 2))$ and subtract the sector synchronicity from the individual stock synchronicity. This gives averages for the corrected synchronicity of -1.75 before and 1.81 after the event. This negative variation suggests a lowering in synchronicity which itself means a disclosure of private information integrated in the stock prices. However the difference between the two values is not significant and suggests many differences between the firms.

\section{INSERT TABLE 1 ABOUT HERE}

\footnotetext{
${ }^{3}$ These values are different at the $10 \%$ level but not at the $5 \%$ level.

${ }^{4}$ After correction of the variation of R2 by subtracting the variation of sector $\mathrm{R} 2$, the difference between corrected R2s after the announcement minus those for before the announcement is -0.0003 . It is not significantly different from zero $(p=0.00)$.
} 


\subsection{Hypotheses}

The CAR and informativeness are different measures of the same signal so they should follow the same trend. This provides our first hypothesis:

H1: Informativeness increases as the CAR increases.

Share repurchase will disclose private specific information. In a signaling approach directed at future prospects, informativeness will increase with share repurchase. The alternative will be that the information disclosed and ensuing from that decision is useless. Our second hypothesis can be split into two sub-hypotheses. As buyback is a discretionary decision, the strength of the signal has a meaning. Moreover, if we take into account the global payout framework of the firm, the signal can be weakened if the dividend policy changes. This is particularly true if repurchase and dividends are substituted. Thus:

H2: Repurchase will develop informativeness, i.e. the dissemination of private information.

H2a: Informativeness increases with the importance of the share buyback. H2b: Informativeness will be limited if the buyback follows a decrease in dividend.

\section{Variables and descriptive statistics}

\subsection{Reaction to the announcement}

We calculate CARs by looking at a window of two calendar weeks around the announcement date. The announcement date occurs during a business day, so the effective window is -5 business days and +5 business days around the event. We look at abnormal returns in two ways. A simple CAR calculation subtracts the relevant market index return from the stock return. This gives an average positive abnormal return of $1.35 \%$. The standard CAR is calculated using the market model returns and subtracting them from the stock returns. The market model is estimated on a previous window of weekly returns from $\mathrm{t}-33 \mathrm{w}$ to $\mathrm{t}-1 \mathrm{w}$; i.e. 32 weekly observations. This gives a positive average CAR value of $+1.21 \%$. However, we note that the CARs are not significantly 
different from zero (see Table 2). This result differs from Grullon and Michaely's (2004) empirical result of a significant event reaction when share repurchase is disclosed.

INSERT TABLE 2 ABOUT HERE

\subsection{Stock market moves}

We calculate the stock market moves before and after the announcement. We neutralize a period of one week before and one week after the announcement date. The stock price move is calculated during a 32-week window before and a 32-week window after i.e. [t$33 w, t-1 w]$ and $[t+1 w, t+33 w]$. During these two periods we calculate the stock return deflated by the corresponding market index return. These data are winsorized in the $2.5 \%-97.5 \%$ band.

\section{INSERT TABLE 3 ABOUT HERE}

The stock move before repurchase is significantly positive before the announcement. This result contradicts that of Ginglinger and Hamon (2007). Post event moves are not significant. We do not see the upside correction as implied by the signaling theory.

\subsection{Sample}

We could only obtain 413 observations of synchronicity from the Thomson Financial database because of the unavailability of data. Many stock prices were missing from the 1990s or the stock did not have related sector indices because the latter were introduced later. Similarly we need to have sufficient data to get the CAR values. This reduces the sample to 412 observations. The total amount of repurchase considered in our sample is USD 467 billion (compared to USD 737 billion in the raw sample). Most of the repurchases occurs in the USA, and European transactions comprise only $18 \%$ of the sample. An annual breakdown shows that some years are more populated than others. Periods of bull markets are those where repurchases are frequent, for instance, pre2000 and 2006-2007. Bearish market conditions do not favor repurchase (after the Internet bubble crash in 2001-2002 and during the financial crisis in 2008-2010). 


\subsection{Other variables}

Several variables characterizing the firm's financial structure and capitalization are considered in the analysis: total capitalization (CAPITALIZATION), enterprise value (ENT_VALUE), and debt leverage (DEBT_TO_CAPITAL). The book value data used in the empirical section are: cash holdings (CASH), equity value (EQUITY_VAL), total assets (TARG_TOT_ASS) and net assets (NET_ASSET). Cash holdings are divided by total assets in the CASH ratio. The MARKT_VALUE gives the equity market value. The firms' market to book ratio (RATIO_OFFER_TO_B) and a proxy of Tobin's Q ratio (VALUE_OV_NET_ASS) are considered. Other firm characteristics are location (US or EU dummies) and profitability: margin (EBITDA_MARGIN) or cash return on assets (EBIT_OV_ASSET or EBITDA_ROA).

The share repurchase transaction is identified by its value (TRANS_VALUE). Dividends are appraised in the prior period (DIV_1Y_BEF and DIV_2Y_BEF). The dynamic of the dividend policy is analyzed through the DIV_VAR variable. Dividend yield is DIV_PERC. Some variables are built to assess the strength of the signal attached to the buyback decision: The size of the repurchase in relation to the market value (ASYMMETRY), and the structure of the payout policy comparing the buyback decision to the dividend decision (DIV_BUYBACK_SIGN). The percentage of shares acquired in the buyback operation is PERC_ACQD_SHARES. The year of the transaction is appraised through the YEAR variable.

Market data are assessed through the stock price (PRICE_1D_PRIOR and PRICE_4W_PRIOR) and its relative variation (PR_MOVE). The premium at the announcement date (PREMIUM) is only available for tender. Open market operations do not display that data. Table 5 presents the list of variables.

INSERT TABLE 5 ABOUT HERE 


\section{Empirical tests}

We first investigate the determinants of the size of the repurchase transaction (see Table 6). This can be assessed in terms of absolute value (TRANS_VALUE) or in relative terms compared to the number of shares available in the market. Table 6 shows that the amount of the repurchase is positively influenced by the cash-flow of the firm. It should be related to the size of the firm as indicated by the positive sign of the total asset variable. Neither the financial leverage decision nor the dividend policy variable seems to influence the amount paid in share repurchase. Buyback transactions in the US seem to be larger by USD 250 million compared to buybacks occurring in the EU.

The relative size of the share repurchase is not explained by financial characteristics or the firm data. In particular, there is no significant mean reverting process where an excessive decline in stock price (EXRETB) explains the size of the share repurchase. The future stock over-performance has a tiny and surprisingly negative relationship with the strength of the buyback signal PERC_ACQD_SHARES. The size of the firm (TARG_TOT_ASS) has a negative effect on the size of the repurchase. Interestingly the dividend policy (DIV_VAR) seems to have a tradeoff relationship with the repurchase policy. An increased dividend in the past will result in a smaller buyback operation as expressed in percentage of acquired shares. However, this relation is only significant at the $10 \%$ level. These results do not invalidate the signaling theory of share repurchase because here we do not explain the trigger of a repurchase but the size of the buyback transaction once initiated.

\section{INSERT TABLE 6 ABOUT HERE}

The consequence of the share repurchase decision is immediate in the signaling approach. The decision should cause an immediate reaction from the market. Table 7 presents the determinants of the CARs at the announcement date.

The CAR is strongly dependent on the prior excess return EXRETB. A stock underperformance is identified when the repurchase occurs; it results in a positive abnormal return. This relationship is in line with the undervaluation signaling theory. However, this does not mean that occasional stock undervaluation in the market is the only determinant of a share repurchase. If this were true, the average value of the EXRETB variable over the sample would have been negative. That is not the case in this 
sample where it is globally negative. This means that the market screens situations where stock undervaluation occurs with a situation where buyback will yield another message. In Equation 5 of Table 7 we split the before event excess return into two variables: One corresponds to the underperformance situation (DUM_NEG_RETB), and the other identifies a situation where there is stock over-performance compared to the market index before the repurchase announcement (DUM_POS_RETB). The coefficient of the former variable is strongly significant and negative (Eq5). This outlines the correction for the undervalued stock price which follows the signal delivered by a share repurchase. This coefficient has important magnitude. A 10\% relative drop in the stock price in the previous 33 weeks will result in a positive CAR of $1.2 \%$. On the other hand, if the stock price is overvalued in the preceding period, the buyback signal does not initiate any significant move at the announcement date. Furthermore, a pessimistic signal is issued: A large market to book ratio in such a situation signals those firms that are potentially overvalued. This initiates a negative correction of the stock price. The variables characterizing high perspectives of opportunity growth (Tobin's Q proxy VALUE_OV_NET ASS or market to book variable RATIO_OFFER_TO_B) are significantly negative in Table 7. This means that share repurchases may signal excessively optimistic perspectives in the market price. The CARs are then negative because the repurchase means lower opportunity growth. This is strictly in line with Grullon and Michaely's (2004) explanation, but not with their results. It explains why the EXRETA variable is not significant: Repurchase will not systematically deliver a signal of good future prospects previously not taken into account in the stock price. The strength of the signal as measured by the percentage of acquired shares is positively linked with the CAR, which is as expected.

\section{INSERT TABLE 7 ABOUT HERE}

We now test the hypotheses by looking at the determinant of informativeness in the stock prices. Table 8 presents regressions explaining the change in synchronicity, VAR_S. A decrease in $S$ means that the stock price is more inflated with private information and that the signal linked to a share repurchase delivers useful information. The first result is the unanimous rejection of the CAR variable (or the CARINDEX variable in Eq.4) to explain change in informativeness. The immediate market reaction or appraisal of the repurchase decision is set on a case-by-case basis. It signals that the price integrates 
new pieces of information but these pieces do not globally improve the level of private information. Sometimes they may, sometimes not, according to the context and the prospects of the firm. CARs are a reaction and the magnitude of the immediate market reaction does not systematically mean an improvement or a decrease in the informativeness of the stock price. Our hypothesis H1 is rejected.

Inversely, the change in dividend policy plays a significant role in delivering private information when a share repurchase occurs. It strongly helps in explaining why the repurchase occurs. The sign of the increase in the dividend variable DIV_VAR is negative. This means that if the dividend rises and at the same time the firm repurchases shares, the signal is important because the firm does not substitute repurchase for the dividend in its payout policy. It qualifies a pure signal strictly readable in terms of a classic signaling approach: past stock undervaluation and/or a question about the future growth opportunities. Conversely, if the dividend decreases, because of the negative sign of VAR_DIV, the synchronicity rises and the informativeness of the stock price decreases. This means that the signal linked to a share repurchase is then poor information: It simply says that the firm is substituting repurchase for the dividend payment in the payout policy. It does not deliver private information on the stock under/overvaluation. This result confirms our hypothesis $\mathrm{H} 2 \mathrm{~b}$ which states that a decrease in dividend will limit informativeness.

The ASYMMETRY variable is positively significant in regressions (1) to (4) in Table 8. This variable is a proxy of the strength of the signal to deliver private information. As ASYMMETRY increases, so the share of public investors decreases and so the asymmetry of information globally reduces. The role of private information is a concern only for outside investors. The synchronicity improves because the asymmetry of information is less acute. The other variables, such as stock before event performance, are nonsignificant. Contrary to our hypothesis $\mathrm{H} 2 \mathrm{a}$, informativeness decreases with the importance of a share buyback transaction. Hence we can question the usefulness of information associated with the share repurchase decision. It does not seem to improve the specific information on the firm to the outside investor, except if associated with a dividend change signal. 


\section{INSERT TABLE 8 ABOUT HERE}

A robustness check is proposed in Equations (5) and (6). The former uses a two-step estimate to take into account possible endogeneity or joint determination between $S$ and the CAR. A first step equation estimates the predicted values of the CAR. We use Equation (5) identified in the CAR model of Table 7. We calculate the residual of the CAR estimates. The CAR residual is used as the endogenous variable in Equation (5) of Table 8. It still is not significant. Equation (6) uses GMM estimates. We use a set of nine instruments (EXRETA, EU, VAL_OV_NET_ASSET, MARKT_VAKUE, TRANS_VALUE, EBITDA_MARGIN, DIV_ERC, DIV VAR, PR_MOVE). As DIV_VAR is used as an instrument, it is not in the regression. The CAR variable is still not significant.

\section{Conclusion}

We use the concept of informativeness to test the signaling hypothesis of share repurchase transactions. The signaling hypothesis by itself is supported by the results. The market reacts to a share repurchase signal. This signal is not clear-cut and needs to be analyzed and scrutinized. The undervaluation story is effective but is too simple. It can combine with a negative story about over-optimism in growth opportunities. These points have been documented in the literature and our paper complements these findings.

The introduction of the informativeness concept to analyze share repurchase is new. Informativeness analyzes the quality and the usefulness of the private information disclosed with a share repurchase. Our empirical test shows that this information is poor. Sometimes the informativeness may increase when the signal linked to a buyback combines well with a positive dividend policy. If the repurchase is viewed as a substitution for dividends in a global payout policy, it does not disclose specific private information to the market. Thus, we can question the informative content of a share repurchase decision. The major result of the analysis in terms of informativeness is that share repurchase does not only tell a story in terms of stock under- or overvaluation but immediately leads to questioning the dividend policy. The relationship with dividend policy should not be viewed in terms of a substitution framework for dividends. Further research will aim to consider repurchase and dividend policy as joint components. 


\section{References}

Allen F., Bernardo A., Welch (2000) A theory of dividend based on tax clientele, J. of Finance 55, 2499-2536

Benartzi, S., Michaely, R., Thaler, R. (1997) Do changes in dividends signal the future or the past? Journal of Finance 52, 1007-1034.

Bernheim D. (1991) Tax policy and the dividend puzzle, Rand Journal of Economics 22, 455-476

Beuselinck, C., Joos, P., Khurana, I., Van der Meulen, S. (2010) Mandatory IFRS Reporting and Stock Price Informativeness, Working paper, Tilburg University.

Chen, Q., Goldstein, I., Jiang W. (2007) Price Informativeness and Investment Sensitivity to Stock Price, Review of Financial Studies 20, 619-650.

Dittmar, A.K. (2000) Why do firms repurchase stock? The Journal of Business 73, 331355.

Durnev, A., Morck, R., Yeung, B., Zarowin, P. (2003) Does Greater Firm-Specific Return Variation Mean More or Less Informed Stock Pricing? Journal of Accounting Research 41, 797-836.

Durnev, A., Morck, R., Yeung, B. (2004) Value-Enhancing Capital Budgeting and FirmSpecific Stock Return Variation, Journal of Finance 59, 65-105.

Eberhart A., Siddique A. (2005) Why are Stock Buyback Announcements Good News? (November 2004). AFA 2005 Philadelphia Meetings Paper. Available at SSRN: http://ssrn.com/abstract=647843 or http://dx.doi.org/10.2139/ssrn.647843 Frésard L. (2012) Cash savings and stock price informativeness, Review of Finance 16(4), 985-1912

Ginglinger E., Hamon J. (2007) Actual share repurchases; timing and corporate liquidity, Journal of Banking and Finance 31(3), 915-938

Grullon G. Michaely R. (2002) Dividends, share repurchases, and the substitution hypothesis, Journal of Finance $59, n^{\circ} 2,651-680$

Grullon, G., Michaely, R, (2004) The information content of share repurchase programs, Journal of Finance 59, 651-680.

Jensen M. (1986) Agency cost of free cash flow, corporate finance, and takeovers, American Economic Review 76(2), 323-329 
Jin, L., Myers, S.C. (2006), R2 around the World: New Theory and New Tests, Journal of Financial Economics 79, 257-292.

John K., Williams J., (1985) Dividends dilution and taxes: a signaling equilibrium, J. of Finance 40, 1053-1070

Loureiro G., Taboada A., (2011) The Impact of IFRS Adoption on Stock Price Informativeness (October 31, 2011), available at SSRN:

http://ssrn.com/abstract=1952593

Martynova M., Renneboog L., (2009) What determines the financing decision in corporate takeovers: Cost of capital, agency problems, or the means of payment, Journal of Corporate Finance 15, 290-315

Morck, R., Yeung, B., Yu, W. (2000) The Information Content of Stock Markets: Why Do Emerging Markets Have Synchronous Stock Price Movement? Journal of Financial Economics 58, 215-260

Piotroski J., Roulstone D. (2004) The influence of analysts, institutional investors, and insiders on the incorporation of market, industry, and firm-specific information into stock prices, The Accounting Review 79, 1119-1151.

Roll R., (1988) R², Journal of Finance vol.43, 541-566.

Vermaelen T. (1984) Repurchase tender offers, signaling and managers incentives, Journal of Financial and Quantitative Analysis 19, 163-181 
Table 1 Synchronicity comparison before and after transactions

(Global sample of repurchase and assimilated transactions; North America and Europe; source: Thomson Financial; 1990-2011 period; 32 weeks window used to calculated the R2s; weekly stock and index variations; Before: $[-33,-1]$ weeks window before the announcement date; After: $[+1,+33]$ weeks window after the announcement date; $\mathrm{R} 2_{\text {raw: }}$ : R-square of equation $R_{i, t}=a_{m, s}+b_{m, s} R_{m, t}+c_{m, s} \varepsilon_{s, t}+\varepsilon_{s, t} ; \mathrm{R} 2$ indsustry: R-square of equation $R_{s, t}=a_{s}+b_{s} R_{m, t}+\varepsilon_{s, t} ;$ Synch raw: raw synchronicity measure $S=\log (R 2 /(1-$ $R 2))$ where R2 raw is used, Synchind: synchronicity measure of the industry index using $\mathrm{R} 2_{\text {industry; }}$ Synch $_{\text {diff: }}$ Modified synchronicity using a correction where the synchronicity of the industry has been subtracted from the raw synchronicity; Diff-in-diff : after announcement synchronicity minus before announcement; P-value: p-value of a T-test of the difference between before and after announcement variables; $N=413$ )

\begin{tabular}{|l|l|l|}
\hline & Mean & Std dev \\
\hline$\underline{\text { R2 }}$ raw & & \\
\hline Before & 0.2778 & 0.2005 \\
\hline After & 0.3044 & 0.2177 \\
\hline p-value & 0.0679 & \\
\hline$\underline{\text { R2 }}$ industry & & \\
\hline Before & 0.6117 & 0.2167 \\
\hline After & 0.6387 & 0.2298 \\
\hline$\underline{\text { Synch }}$ raw & & \\
\hline Before & -1.3123 & 1.3858 \\
\hline After & -1.1885 & 1.4627 \\
\hline p-value & 0.2125 & \\
\hline$\underline{\text { Synch }}$ ind & & \\
\hline Before & 0.4432 & 1.5192 \\
\hline After & 0.6238 & 1.3735 \\
\hline Synch & & \\
\hline Before & -1.7555 & 1.9676 \\
\hline After & -1.8123 & 1.7214 \\
\hline Diff-in-diff & -0.0568 & \\
\hline p-value & 0.6594 & \\
\hline & & \\
\hline
\end{tabular}


Table 2 Abnormal returns at the share repurchase announcement date

(Sample of share repurchase; North America and Europe; source: Thomson Financial; 1990-2011 period; cumulative abnormal returns calculated during a period of 10 business days $[-5 d,+5 d]$; parameter of the market model are estimated using weekly returns during an estimation period of 32 weeks prior to the estimation, period [t$33 \mathrm{w}, \mathrm{t}-1 \mathrm{w}], \mathrm{R}_{\mathrm{t}}-\mathrm{R}_{\mathrm{m}}$ is the simple difference between the stock return and the index return, CAR(MM) is the abnormal returns calculated using the market model returns data are winsorized using the $2.5-97.5 \%$ range of initial observations; 395 data)

\begin{tabular}{|l|l|l|}
\hline & CAR $\left(\mathrm{R}_{\mathrm{t}}-\mathrm{R}_{\mathrm{m}}\right)$ & CAR $(\mathrm{MM})$ \\
\hline Mean & 0.01339 & 0.01215 \\
\hline Standard dev. & 0.06004 & 0.06108 \\
\hline p-value & 0.00 & 0.00 \\
\hline
\end{tabular}

Table 3 Stock price moves and excess returns before and after the announcement of share repurchase

(Sample of share repurchase; North America and Europe; source: Thomson Financial; 1990-2011 period; 1990-2011 period, , excess returns are calculated by subtracting the relevant market returns to the stock returns for the two time periods: before announcement (32 weeks prior period [t-33w,t-1w]); After: after announcement (32 weeks subsequent period [ $\mathrm{t}+1 \mathrm{w}, \mathrm{t}+33 \mathrm{w}])$; data are winsorized using the $2.5-97.5 \%$ range of initial observations; 395 usable observations)

\begin{tabular}{|l|l|l|}
\hline Excess return & Before & After \\
\hline Mean & 0.01598 & 0.00482 \\
\hline Standard dev. & 0.19986 & 0.18612 \\
\hline p-value & 0.06 & 0.31 \\
\hline
\end{tabular}


Table 4 Sample characteristics

(European, Canadian and US share repurchases; completed transaction with minimum value of 50 million dollars; repurchase or self-tender; only repayment by cash (or cash dividend); only publicly listed and non-financial firms; deals with not enough observations to calculate synchronicity and CARs are excluded; European transactions: firms located in Belgium, France, Germany, Italy, Netherlands, Spain, or United Kingdom; source: Thomson Financials; period 2000-2011; N: 412)

\begin{tabular}{|c|c|c|c|}
\hline \multicolumn{4}{|l|}{ Panel A } \\
\hline & US buybacks & $\begin{array}{l}\text { European and } \\
\text { Canadian buybacks }\end{array}$ & \\
\hline Total amount (B USD) & 384,76 & 82,96 & \\
\hline Average transaction (M USD) & 1229,2 & 838,0 & \\
\hline Standard deviation (M USD) & 11919,7 & 506,2 & \\
\hline $\mathrm{N}$ & 313 & 99 & \\
\hline \multicolumn{4}{|l|}{ Panel B } \\
\hline Country & & Year & \\
\hline USA & 313 & 2011 & 40 \\
\hline Canada & 26 & 2010 & 20 \\
\hline Netherlands & 21 & 2009 & 11 \\
\hline UK & 17 & 2008 & 18 \\
\hline France & 12 & 2007 & 41 \\
\hline Germany & 10 & 2006 & 34 \\
\hline Italy & 6 & 2005 & 31 \\
\hline Spain & 5 & 2004 & 26 \\
\hline \multirow[t]{6}{*}{ Belgium } & 2 & 2003 & 17 \\
\hline & & 2002 & 11 \\
\hline & & 2001 & 8 \\
\hline & & 2000 & 24 \\
\hline & & 1995-99 & 109 \\
\hline & & 1990-94 & 22 \\
\hline
\end{tabular}


Table 5 List of variables

\begin{tabular}{|c|c|}
\hline ASYMMETRY & $\begin{array}{l}\text { Relative strength of the buyback decision compared to } \\
\text { the stock market value. Ratio of TRANS_VALUE to } \\
\text { MARKT_VALUE }\end{array}$ \\
\hline CAPITALIZATION & $\begin{array}{l}\text { Capitalization using the most current financial } \\
\text { information: prior to the announcement: shareholder's } \\
\text { equity, plus long-term debt, plus short-term debt }\end{array}$ \\
\hline CAR & $\begin{array}{l}\text { Cumulative abnormal stock return. Returns are } \\
\text { cumulated over the period } 1 \text { week before and } 1 \text { week } \\
\text { after the announcement date (10 business days). Market } \\
\text { model is used to get the abnormal returns. Model } \\
\text { parameters are priory estimated using } 32 \text { weekly } \\
\text { returns. Data are winsorized using the } 1 \%-99 \% \text { range. }\end{array}$ \\
\hline CARINDEX & $\begin{array}{l}\text { Cumulative abnormal returns using market index returns } \\
\text { over the }[-1 w,+1 w] \text { period surrounding the } \\
\text { announcement date. Data are winsorized using the } 1 \%{ }^{-} \\
99 \% \text { range. }\end{array}$ \\
\hline $\mathrm{CASH}$ & Ratio of CASH_MKTBLE_SEC to TARG_TOTAL_ASS \\
\hline CASH_MAKTBLE_SEC & Cash and marketable securities (M\$) \\
\hline DEBT_TO_CAPITAL & $\begin{array}{l}\text { Ratio of Long-Term Debt to Total Capitalization: Target } \\
\text { long term debt divided by total capitalization as long- } \\
\text { term debt, plus short-term debt, plus equity }\end{array}$ \\
\hline DIV_1Y_BEF & Dividend paid 1 year prior $(\mathrm{M} \$)$ \\
\hline DIV_2Y_BEF & Dividend paid 2 years prior $(\mathrm{M} \$)$ \\
\hline DIV_BUYBACK_SIGNAL & $\begin{array}{l}\text { Strength of the buyback signaling decision compared to } \\
\text { the dividend decision. Ratio of the dividend paid in the } \\
\text { last year to the amount of the buyback transaction. } \\
\text { DIV_1Y_BEF over TRANS_VALUE. }\end{array}$ \\
\hline DIV_PERC & $\begin{array}{l}\text { Dividend yield. Last year divided by the net assets, } \\
\text { DIV_1Y_BEF over NET_ASST }\end{array}$ \\
\hline DIV_VAR & $\begin{array}{l}\text { Variation in \% of the paid dividends between } 1 \text { year } \\
\text { before the event and } 2 \text { years before. Ratio of DIV_1Y_BEF } \\
\text { to DIV_2Y_BEF minus } 1 \text {. }\end{array}$ \\
\hline EBIT_OV_ASSET & EBIT return over asset: EBIT divided by total asset (\%) \\
\hline EBITDA_MARGIN & Ratio of EBITDA to sales \\
\hline EBITDA_ROA & Ratio of EBITDA to total assets \\
\hline ENT_VALUE & $\begin{array}{l}\text { Enterprise value based on financials: number of shares } \\
\text { multiplied by the offer price, plus convertibles, plus short } \\
\text { term and long-term debt, minus cash and marketable } \\
\text { securities }\end{array}$ \\
\hline EQUITY_VALUE & $\begin{array}{l}\text { Equity value based on financials: number of share } \\
\text { multiplied by the offer price }\end{array}$ \\
\hline EU & $\begin{array}{l}\text { Firm incorporated in Belgium, France, Italy, Germany, } \\
\text { Netherlands, Spain, or UK }\end{array}$ \\
\hline EXRETA & $\begin{array}{l}\text { Stock excess return after the announcement over the } \\
{[t+1 w, t+33 w] \text { period. Relevant market index is }} \\
\text { subtracted from the stock returns (no dividend). }\end{array}$ \\
\hline
\end{tabular}




\begin{tabular}{|c|c|}
\hline EXRETB & $\begin{array}{l}\text { Stock excess return before the announcement over the [t- } \\
33 \mathrm{w}, \mathrm{t}+-1 \mathrm{w} \text { ] period. Relevant market index is subtracted } \\
\text { from the stock returns (no dividend). }\end{array}$ \\
\hline MARKT_VALUE & Equity market value (M\$) \\
\hline NET_ASSET & Total asset minus total liabilities (M\$) \\
\hline PERC_ACQD_SHARES & Percentage of shares acquired in the repurchase \\
\hline PR_MOVE & $\begin{array}{l}\text { Stock price move during the last month before the } \\
\text { announcement. Ratio of price } 1 \text { day before divide by the } \\
\text { price } 4 \text { weeks before minus } 1 .\end{array}$ \\
\hline PREMIUM & $\begin{array}{l}\text { Offer price to target stock price } 4 \text { weeks prior to } \\
\text { announcement (\%) }\end{array}$ \\
\hline PRICE_1D_PRIOR & Closing stock price 1 day before announcement (\$) \\
\hline PRICE_4W_PRIOR & Closing stock price 4 weeks before announcement (\$) \\
\hline RATIO_OFFER_TO_BOOK & $\begin{array}{l}\text { Ratio of offering price to target book value: Offering price } \\
\text { in the deal divided by target's book value per share as of } \\
\text { the date of the most current financial information prior } \\
\text { to the announcement of the transaction. Adjusted market } \\
\text { to book ratio }\end{array}$ \\
\hline S_AFTER & $\begin{array}{l}\text { Synchronicity } S \text { of the stock price after the } \\
\text { announcement looking at the }[\mathrm{t}+1 \mathrm{w}, \mathrm{t}+33 \mathrm{w}] \text { window. } \\
\text { Calculated using the R2 of the regression versus the } \\
\text { relevant market and the sector indices. We use the } \\
\text { transformation } S=\log (R 2 /(1-R 2)) \text {. }\end{array}$ \\
\hline S_BEF & $\begin{array}{l}\text { Synchronicity of the stock price before the } \\
\text { announcement looking at the }[\mathrm{t}-33 \mathrm{w}, \mathrm{t}-1 \mathrm{w}] \text {. See S_AFTER. }\end{array}$ \\
\hline TARGET TOT ASS & Total asset (M\$) \\
\hline TRANS_VALUE & Value of transaction (M\$) \\
\hline US & US firms \\
\hline VALUE_OV_NET_ASSET & $\begin{array}{l}\text { Firm valued at the deal value over net asset. Adjusted } \\
\text { market to book value }\end{array}$ \\
\hline VAR_S & $\begin{array}{l}\text { Variation of synchronicity after the event compared to } \\
\text { before, S_AFTER minus S_BEF. Data are winsorized using } \\
\text { the } 1 \%-99 \% \text { range. }\end{array}$ \\
\hline YEAR & Year of the transaction \\
\hline
\end{tabular}


Table 6 Determinants of the amount of the share repurchase in absolute and relative terms

(European, Canadian and US share repurchases; completed transaction with minimum value of 50 million dollars; repurchase or selftender; only repayment by cash (or cash dividend); only publicly listed and non-financial firms; deals with not enough observations to calculate synchronicity and CARs are excluded; 1990-2011; dependent variables are TRANS_VALUE: amount of share repurchase in \$; PERC_ACQD_SHARES: percentage of the capital acquired in the transaction; DEBT_TO_CAPITAL: Ratio of long-term debt to total Capitalization (long term and short term debt plus equity); DIV_PERC: Dividend yield over net asset; DIV_VAR: Variation in \% of the paid dividends between 1 year before the event and 2 years before; EBIT_OV_ASSET: EBIT divided by total asset (\%); EXRETA: Stock excess return after the announcement over the $[t+1 \mathrm{w}, \mathrm{t}+33 \mathrm{w}]$ period; EXRETB: Stock excess return before the announcement over the [t-33w, t+-1w] period; EU: Firm incorporated in Belgium, France, Italy, Germany, Netherlands, Spain, or UK; PR_MOVE: ratio of stock price move during the last month before the announcement; TARG_TOT_ASS: Total asset (M\$); robust covariance estimate are used to adjust for heteroscedasticity; a: 1\% significance level; b: 5\% significance level; c: 10\% significance level) 


\begin{tabular}{|c|c|c|c|c|c|c|c|c|c|c|c|c|c|}
\hline \multirow{3}{*}{$\begin{array}{l}\text { Dep. Var } \\
\text { Variables }\end{array}$} & \multicolumn{3}{|c|}{ (Eq1) } & \multicolumn{4}{|c|}{ (Eq2) } & \multicolumn{3}{|c|}{$\begin{array}{l}\text { (Eq3) } \\
\text { PERC ACQD SHARES }\end{array}$} & \multicolumn{3}{|c|}{ (Eq4) } \\
\hline & \multicolumn{3}{|c|}{ TRANS VALUE } & \multicolumn{4}{|c|}{ TRANS VALUE } & \multicolumn{3}{|c|}{ PERC ACQD SHARES } & \multicolumn{3}{|c|}{ PERC ACQD SHARES } \\
\hline & $\underline{\text { Coeff }}$ & $\underline{\text { T-Stat }}$ & $\underline{\text { Signif }}$ & $\underline{\text { Coeff }}$ & $\underline{\text { T-Stat }}$ & $\underline{\text { Signif }}$ & & $\underline{\text { Coeff }}$ & $\underline{\text { T-Stat }}$ & $\underline{\text { Signif }}$ & $\underline{\text { Coeff }}$ & T-Stat & $\underline{\text { Signif }}$ \\
\hline Constant & -214.5615 & -0.7549 & 0.45 & -414.5658 & -1.1951 & 0.23 & Constant & 10.1644 & 3.7727 & $0.00 a$ & 14.9243 & 11.2754 & $0.00 a$ \\
\hline TARG_TOT_ASS & 0.0457 & 5.4259 & $0.00 a$ & 0.0630 & 3.8689 & $0.00 a$ & EXRETB & -9.5973 & -1.4256 & 0.15 & & & \\
\hline DIV_VAR & -47.4288 & -0.2852 & 0.78 & & & & DEBT_TO_CAPITAL & 2.7933 & 0.5876 & 0.56 & & & \\
\hline EXRETB & 34.4998 & 0.1261 & 0.90 & & & & EBIT_OV_ASSET & 17.8373 & 0.9557 & 0.34 & & & \\
\hline DIV_PERC & 301.7245 & 0.4028 & 0.69 & & & & TARG_TOT_ASS & & & & -0.0001 & -1.9616 & $0.05 b$ \\
\hline EU & & & & -719.2077 & -2.4673 & $0.01 b$ & PR_MOVE & & & & 1.9658 & 0.1774 & 0.86 \\
\hline PR_MOVE & & & & -250.9988 & -0.3549 & 0.72 & & & & & & & \\
\hline R2 & 0.38 & & & 0.29 & & & & 0.03 & & & 0.06 & & \\
\hline $\mathrm{N}$ & 311 & & & 353 & & & & 186 & & & 196 & & \\
\hline
\end{tabular}


Table 7 Determinants of the CARs at repurchase announcement date

(European, Canadian and US share repurchases; completed transaction with minimum value of 50 million dollars; repurchase or selftender; only repayment by cash (or cash dividend); only publicly listed and non-financial firms; deals with not enough observations to calculate synchronicity and CARs are excluded; 1990-2011; dependent variable is CAR: cumulative abnormal return over 10 business days around the announcement date; PERC_ACQD_SHARES: percentage of the capital acquired in the transaction; DIV_BUYBACK_SIGN: Strength of the buyback signaling decision compared to the dividend decision, ratio of the dividend paid in the last year to the amount of the buyback transaction; DUM_POS_RETB: only positive prior excess returns EXRETB values; DUM_NEG_RETB: only negative prior excess returns EXRETB values; EXRETA: Stock excess return after the announcement over the [ $t+1 \mathrm{w}, \mathrm{t}+33 \mathrm{w}]$ period; EXRETB: Stock excess return before the announcement over the $[t-33 w, t+-1 w]$ period; EU: Firm incorporated in Belgium, France, Italy, Germany, Netherlands, Spain, or UK; RATIO_OFFER_TO_B: Ratio of the firm valued at the offering Price to book value; VALUE_OV_NET_ASSET: Firm valued at the deal value over net asset; robust covariance estimate are used to adjust for heteroscedasticity; a: $1 \%$ significance level; b: 5\% significance level; c: $10 \%$ significance level) 


\begin{tabular}{|c|c|c|c|c|c|c|c|c|c|c|c|c|c|c|c|}
\hline & (Eq1) & & & (Eq2) & & & (Eq3) & & & (Eq4) & & & (Eq5) & & \\
\hline Dep. Var & CAR & & & CAR & & & CAR & & & CAR & & & CAR & & \\
\hline Variables & Coeff & $\underline{\text { T-Stat }}$ & $\underline{\text { Signif }}$ & $\underline{\text { Coeff }}$ & T-Stat & $\underline{\text { Signif }}$ & Coeff & T-Stat & $\underline{\text { Signif }}$ & $\underline{\text { Coeff }}$ & T-Stat & $\underline{\text { Signif }}$ & $\underline{\text { Coeff }}$ & T-Stat & $\underline{\text { Signif }}$ \\
\hline Constant & 0.0088 & 1.1016 & 0.27 & 0.0119 & 1.4640 & 0.14 & & & & & & & & & \\
\hline EXRETA & -0.0204 & -0.7020 & 0.48 & -0.0153 & -0.5294 & 0.59 & & & & & & & & & \\
\hline EXRETB & -0.0587 & -2.4094 & $0.02 b$ & -0.0569 & -2.3553 & $0.02 b$ & -0.0529 & -2.5012 & $0.01 b$ & -0.0515 & -2.3818 & $0.02 b$ & & & \\
\hline VALUE_OV_NET_ASS & -0.0004 & -11.8779 & $0.00 a$ & & & & & & & & & & & & \\
\hline RATIO_OFFER_TO_B & & & & -0.0005 & -4.2879 & $0.00 a$ & -0.0003 & -2.8567 & $0.00 a$ & -0.0004 & -3.6108 & $0.00 a$ & -0.0004 & -4.0864 & $0.00 a$ \\
\hline DIV_BUYBACK_SIGN & 0.0032 & 0.1631 & 0.87 & 0.0025 & 0.1251 & 0.90 & 0.0284 & 2.2702 & $0.02 b$ & & & & & & \\
\hline EU & 0.0125 & 1.0049 & 0.31 & 0.0100 & 0.8019 & 0.42 & & & & & & & & & \\
\hline PERC_ACQD_SHARES & 0.0005 & 2.1763 & $0.03 b$ & 0.0005 & 2.1709 & $0.03 b$ & & & & 0.0009 & 4.1937 & $0.00 a$ & 0.0005 & 2.5244 & $0.01 b$ \\
\hline DUM_POS_RETB & & & & & & & & & & & & & 0.0045 & 0.1604 & 0.87 \\
\hline DUM_NEG_RETB & & & & & & & & & & & & & -0.1183 & -3.5151 & $0,00 a$ \\
\hline R2 & 0.07 & & & 0.09 & & & 0.02 & & & 0.06 & & & 0.08 & & \\
\hline $\mathrm{N}$ & 204 & & & 204 & & & 222 & & & 213 & & & 223 & & \\
\hline
\end{tabular}


(European, Canadian and US share repurchases; completed transaction with minimum value of 50 million dollars; repurchase or selftender; only repayment by cash (or cash dividend); only publicly listed and non-financial firms; deals with not enough observations to calculate synchronicity and CARs are excluded; 1990-2011; dependent variable is VAR_S: Variation of synchronicity after the event compared to before, S_AFTER minus S_BEF; ASYMMETRY: Relative strength of the buyback decision compared to the stock market value, ratio of TRANS_VALUE to MARKT_VALUE; CAR: cumulative abnormal return over 10 business days around the announcement date, calculated using the market model; CARINDEX: Cumulative abnormal return calculated using the simple market index ; DIV_PERC: Dividend yield over net asset; DIV_VAR: Variation in \% of the paid dividends between 1 year before the event and 2 years before; DIV_BUYBACK_SIGN: Strength of the buyback signaling decision compared to the dividend decision, ratio of the dividend paid in the last year to the amount of the buyback transaction; DUM_POS_RETB: only positive prior excess returns EXRETB; DUM_NEG_RETB: only negative prior excess returns EXRETB; EBITDA_MARGIN: Ratio of EBITDA to sales; EXRETA: Stock excess return after the announcement over the $[\mathrm{t}+1 \mathrm{w}, \mathrm{t}+33 \mathrm{w}]$ period; EXRETB: Stock excess return before the announcement over the $[\mathrm{t}-33 \mathrm{w}$, $\mathrm{t}+-1 \mathrm{w}]$ period; EU: Firm incorporated in Belgium, France, Italy, Germany, Netherlands, Spain, or UK; MARKT_VALUE: Equity market value (M\$); NET_ASSET: Total asset minus total liabilities (M\$); PERC_ACQD_SHARES: percentage of the capital acquired in the transaction; PR_MOVE: ratio of stock price move during the last month before the announcement; RATIO_OFFER_TO_B: Ratio of the firm valued at the offering Price to book value; S_AFTER: Synchronicity $S$ of the stock price after the announcement looking at the [ $t+1 \mathrm{w}, \mathrm{t}+33 \mathrm{w}]$ window; S_BEF: Synchronicity of the stock price before the announcement looking at the [t-33w, t-1w]; TRANS_VALUE: Value of transaction (M\$); VALUE_OV_NET_ASSET: Firm valued at the deal value over net asset; Eq5 is a two-step estimate, the CAR variable is estimated using an OLS regression on the following regressors: DUM_POS_RETB DUM_NEG_RETB RATIO_OFFER_TO_B PERC_ACQD_SHARES, residuals of this estimate is variable CARresidual and is used as regressor in Eq5; Eq6 uses the following instruments: EXRETA, EU, VAL_OV_NET_ASSET, MARKT_VAKUE, TRANS_VALUE, EBITDA_MARGIN, DIV_PERC, DIV VAR, PR_MOVE; OLS with robust covariance estimate are used to adjust for heteroscedasticity; Eq6 uses GMM estimation; a: 1\% significance level; b: 5\% significance level; c: 10\% significance level) 


\begin{tabular}{|c|c|c|c|c|c|c|c|c|c|c|c|c|c|c|c|c|c|c|}
\hline & (Eq1) & & & (Eq2) & & & (Eq3) & & & (Eq4) & & & (Eq5) & & & (Eq6) & & \\
\hline Dep. Var & VAR_S & & & VAR_S & & & VAR_S & & & VAR_S & & & VAR_S & & & VAR_S & & \\
\hline Variable & Coeff & T-Stat & Signif & Coeff & T-Stat & Signif & Coeff & T-Stat & Signif & Coeff & T-Stat & Signif & Coeff & T-Stat & Signif & Coeff & T-Stat & Signif \\
\hline Constant & 0.1793 & 1.1290 & 0.26 & -0.0649 & -0.6979 & 0.49 & -0.0053 & -0.0622 & 0.95 & 0.0342 & 0.4114 & 0.68 & 0.0830 & 0.7344 & 0.46 & -0.1209 & -0.6096 & 0.54 \\
\hline CAR & 1.6118 & 0.9418 & 0.35 & 1.2371 & 0.9767 & 0.33 & 1.4776 & 1.1566 & 0.25 & & & & & & & 8.7049 & 1.0576 & 0.29 \\
\hline CAR residual & & & & & & & & & & & & & 2.3972 & 1.3778 & 0.17 & & & \\
\hline DIV_VAR & -0.6591 & -1.7891 & $0.07 c$ & -0.3937 & -3.9258 & $0.00 a$ & -0.3234 & -3.7412 & $0.00 a$ & -0.3581 & -4.0393 & $0.00 a$ & -0.4712 & -1.4279 & 0.15 & & & \\
\hline ASYMMETRY & 0.0169 & 7.3343 & $0.00 a$ & 0.0001 & 19.8200 & $0.00 \mathrm{a}$ & 0.0001 & 15.4651 & $0.00 a$ & 0.0001 & 15.3953 & $0.00 a$ & 0.0181 & 8.5399 & $0.00 a$ & 0.0261 & 2.7721 & $0.01 \mathrm{~b}$ \\
\hline EXRETB & 0.1139 & 0.1745 & 0.86 & & & & -0.0663 & -0.1472 & 0.88 & -0.3089 & -0.7101 & 0.48 & 0.0089 & 0.0148 & 0.99 & 1.0811 & 0.5095 & 0.61 \\
\hline EXRETA & -0.2281 & -0.3677 & 0.71 & & & & & & & & & & & & & & & \\
\hline PERC_ACQD_SHARES & -0.0064 & -1.1117 & 0.27 & & & & & & & & & & & & & & & \\
\hline NET_ASSET & 0.0000 & -0.6414 & 0.52 & & & & & & & & & & & & & & & \\
\hline DIV_BUYBACK_SIGN & & & & 0.2725 & 1.8521 & $0.06 c$ & & & & & & & & & & & & \\
\hline CARINDEX & & & & & & & & & & 0.7343 & 0.4816 & 0.63 & & & & & & \\
\hline R2 & 003 & & & בח & & & בח0 & & & בח0 & & & 003 & & & J-stat: 5.31 & $08 \mathrm{p}$-val: & \\
\hline $\mathrm{N}$ & 185 & & & 358 & & & 344 & & & 343 & & & 191 & & & 177 & & \\
\hline
\end{tabular}

